\title{
Trees, Rivers and Gods: \\ Paganism in the Work of Martin Heidegger
}

\author{
Martin Travers \\ Griffith University, Brisbane, Australia
}

\begin{abstract}
The concern that Heidegger voiced in his later work for the plight of nature in a world dominated by technological rationality and commercial exploitation has often been seen as a commitment to environmental ethics. This paper argues that the roots of Heidegger's concern lay elsewhere, most notably in his identification with the beliefs and practices of Germanic paganism. Beginning with a discussion of Heidegger's notion of the 'Geviert' (the 'fourfold'), this paper examines how Heidegger drew upon the elemental tropes of the pagan mind, most noticeably those that celebrated water, land and forest, to ground his appropriation of nature in an ethos of spiritualised naturalism.
\end{abstract}

\section{Key words}

Heidegger, paganism, ecology, environmental politics, pantheism, philosophy of nature, Germanic mythology

In 1922, Martin Heidegger observed, in words that were intended as background to his own explorations into 'the purpose of a history of ontology and logic', that 'every interpretation is relative [...] to the particular hermeneutical situation at the time'. Relativism is the preliminary step in philosophical enquiry (2002a: 111). Heidegger would have been the first to have realised that this hermeneutic principle would eventually and necessarily be applied to his own work, as it was, for example, in the 1950s when, following the publication of Sartre's Being and Nothingness (1943), it seemed natural to read Heidegger's earlier Being and Time (1927) from an existential perspective, and to move the interpretative focus away from the phenomenological 
analysis of the conditions of Being to the predicament of Dasein, plagued by anxiety and fear of death (Kleinberg: 137-138).

The same hermeneutical relativism is evident in recent approaches to Heidegger's writing on technology and the technological exploitation of nature, an issue that he explored in his later work, most notably the lecture series 'Insight into That Which Is' (1949), and the essays 'Building Dwelling Thinking' (1951) and 'The Question concerning Technology' (1954). Environmental theorists have often seen these texts as evidence of a philosophy that reveals clear affinities with 'bioregionalism, ecological holism and deep ecology' (Foltz: 174). According to one commentator, Heidegger's 'later writings sought to redefine humankind and nature so to envision an alternative to industrial ideologies that justify treating humans and nonhumans alike as commodities' (Zimmerman: 60). What Heidegger teaches is that 'humankind's highest possibility and obligation is not to dominate nature through technological means, but rather to "let things" in the twofold sense of allowing them to manifest themselves according to their own possibilities, and of allowing them to pursue their own destinies with as little interference as possible' (Zimmerman: 60).

There is, certainly, much in Heidegger's later writing that seems to confirm this reading of his work. It is undeniable that Heidegger was concerned with the rise of technology and the increasing presence of the technological mindset which, as he explained in 'The Question Concerning Technology', 'puts to nature the unreasonable demand that it supply energy that can be extracted and stored as such' (1977: 14). As he further explains, this is a system in which 'the energy concealed in nature is unlocked, what is unlocked is transformed, what is transformed is stored up, what is stored up is, in turn, distributed, and what is distributed is switched about even anew' (1977: 16). Technology reveals nature, but only in a form that is capable of pragmatic manipulation, as something that has nothing to offer beyond its immediate use as a commodity or 'standing reserve' ('Bestand'). The river Rhine, for example, once celebrated by the poet Hölderlin as a source of mythic life, is now seen merely as a store of hydraulic pressure, 'which sets going the electric current for which the longdistance power station and its network of cables are set up to dispatch electricity'(1977: 16). Nature has lost its integrity through commercial exploitation. The primal manifestation of 'Phusis', of helping rather than controlling nature, has been lost in the modern period: Everything is seen as raw material, 'Bestand'. As Heidegger points out: 
The work of the peasant did not challenge the soil of the field. In the sowing of the grain it placed the seed in the keeping of the forces of growth and watched over its increase. But meanwhile even the cultivation of the field has come under the grip of another kind of setting-in-order, which sets upon [stellt] nature. It sets upon it in the sense of challenging it. Agriculture is now the mechanised food industry. Air is now set upon to yield nitrogen, the earth to yield ore, ore to yield uranium, for example; uranium is set upon to yield atomic energy, which can be released either for destruction or for peaceful use (1977: 15).

In such a system the human element disappears; or, more accurately, it does appear but only in the form of a positioned instrumentality, as something that exists to promote and make possible control of nature. Heidegger named this mechanism of positioning, and the mentality that supported it, 'en-framing' ('Ge-stell'). En-framing 'is the way in which the real reveals itself as standing reserve' (1977: 23). As one commentator has noted, en-framing 'is the collection of impositions in which is included the imposition upon humans to impose on things in turn, i.e., to look upon things in the spirit of modern technology, to look upon things as disposables' (Rojcewicz: 195). It is a system that is all-absorbing because it seems to be ceaseless. The present never arrives, but is continually absorbed into a future destination: the product.

Heidegger's depiction of modern technology in 'The Question concerning Technology' would seem to confirm him as a seminal theorist within the environmental movement of post-war Europe. But what is often overlooked by Heidegger's ecological promoters is that the philosopher's critique of technology and his notion of 'en-framing' were typically formulated within the context of, and in contradistinction to, a second major concept that is also woven into Heidegger's narrative of modernity: the 'fourfold' (the 'Geviert'). If en-framing takes us increasingly further into the machinations of modernity, the fourfold takes us (or, at least, shows us a path that will take us) out of modernity. Although the fourfold confronts en-framing as its paradigmatic antimony, as a concept it is rarely noted in ecological readings of Heidegger's work. And for good reason: the fourfold ultimately transcends the pragmatic concerns of environmental ethics, and moves into a quite different conceptual terrain, one that has but a distant affinity with ecology: Heidegger's celebration of the wonder of nature and the immanence of the godhead in 
the physical world. The notion of the fourfold shows that what lies behind Heidegger's concern for the destruction of nature in the modern world is, ultimately, not a dedication to environmental policies and even less to 'green' activism (both, in fact, he would have argued, are simply inverse manifestations of the instrumental logic of en-framing), but a reverence for 'the hidden fullness and wealth of what has been and what, thus gathered, is presencing, of the divine' (1971: 184).

It is in his concept of the fourfold that Heidegger brings together the diverse elements of this vision of a spiritualised nature. In his essay, 'The Thing' ('Das Ding'), the first lecture in the series 'Insight into That Which Is' ('Einsicht in das was ist', 1949-1950), Heidegger explained that simple objects, such as a jug, derive their presence, their internal Being, from the four components of the fourfold, which Heidegger described in the following way:

The earth is that which builds and carries, which bears fruit in nearing, and which tends waters and stones, plants and animals. The sky is the course of the sun, the path of the moon, the shining of the stars, the seasons of the year, light and twilight of the sky, darkness and brightness of the night, favour and desolateness of the weather, passage of clouds and the blue depth of the ether [...] The immortals are the hinting messengers of divinity. Out of their concealed reign, the god appears in its essence, which withdraws from any comparison with what is present $[\ldots]$ The mortals are the humans. They are called mortals because they can die. To die means capable of death as death. Only the human dies (2012: 16).

Although Heidegger's model of the fourfold comes in the end phase of his philosophy, that of the so-called 'late' or 'later' Heidegger, it has its origins in texts written some twenty years earlier, most notably in the essay 'The Origin of the Work of Art' (1935), and in his Contributions to Philosophy (Enowning) (1936-1938). Here, in the latter work, in a section dedicated to the analysis of Da-sein', we are told that 'breaking-out and abandonment, hint and returning [the polarity in which Dasein finds itself] all belong together as the occurrences of owning, in which Enowning opens itself apparently seen only from man's perspective (cf ownhood)'. Heidegger then represents this relationship by means of a diagram that links man and gods (on a horizontal level) with world and earth (along a vertical axis) (1999: 218). Elements of the fourfold also appear in Heidegger's work of art essay. Here, within an Attic context, the philosopher celebrates the elemental constitution of the Greek mind, 
which drew upon 'the grace of the sun [which] first brings to light the light of the day, the breadth of the sky, the darkness of the night' (1971: 42).

It was not, however, until Heidegger's essays on Hölderlin that the fourfold acquired a detailed and defining presence in his work. These essays were written (typically as lectures) over a number of years, beginning with 'Hölderlin and the Essence of Poetry' (1936), and culminating in 'Hölderlin's Earth and Heaven' (1959), in which Heidegger provided his most extended and graphic statement of the 'Urgeviert' (the foundational or preliminary model of the fourfold). In his exegesis of Hölderlin's poem 'As When on a Holiday ...', in the essay of the same name from 1939, Heidegger had noted that in Hölderlin's cosmography 'nature comes to presence in human work and in the destiny of peoples, in the stars and the gods, but also in stones, growing things, and animals, as well as in streams and in thunderstorms' (2000a: 75). It is a view of nature as 'natura naturans', the unmediated presence of what is, a plenitude called by the Greeks 'phusis', which for Heidegger meant 'that rising-up which goes-back-into-itself; it names the coming to presence of that which dwells in the rising-up and thus comes to presence as open' (2000a: 79). Nature is something, Heidegger adds, quoting Hölderlin's translation of Pindar, that is 'begotten out of holy chaos' (2000a: 84).

In his later Hölderlin essay, the study of the hymn 'Der Ister' of 1941, the occasional remarks of the earlier exegeses have come to form the basis of a more grounded philosophy, which is partly still that of Hölderlin but also clearly (and increasingly) that of Heidegger himself. Now nature is not simply viewed as an inchoate plenitude, but as a reality that finds its identity in a tangible place: in land, in the earth and in rivers, in this case the Ister (the pre-Germanic name for the Danube) in celebration of which Hölderlin wrote an unpublished hymn. In his reading of the hymn, Heidegger interprets the river as 'a journeying', as a movement through space. It demarcates, and hence is vital to the defining of space as territory, 'the locality of the locale' (1996: 30). As he further explains, 'the journeying that the river is prevails, and does so essentially, in its vocation of attaining the earth as the 'ground' of the homely', and Heidegger cites a further poem by Hölderlin, 'The Journey' ('Die Wanderung'), which celebrates 'the river's vanishing and flowing in relation to attaining mother earth' (1996: 30). Nature here has a direction that takes it beyond the 'phusis' of the eternally potential. As the philosopher explains elsewhere: 
The river now makes possible for the land a definite space and a circumscribed place ['Ort'] of settlement, of traffic, for the people a cultivable land that guarantees their immediate being-there. The river is not a watercourse that simply passes by the place of men. Rather, its flowing, as it forms the land, founds the possibility of establishing the dwelling of men (1980: 264).

But where is 'the dwelling'? Where is 'the land'? For these entities are not mere abstractions, metaphors that point beyond themselves, simply carrying meaning to something 'higher'. As Heidegger made clear at the beginning of his essay on 'Der Ister', 'Hölderlin's poetry [is] not concerned with images in a symbolic or metaphysical sense' (1996: 30). Meaning remains within its expression. The symbolic is literal. The meaning of the river, as with the other components of Hölderlin's cosmography, land, sky and woodland, has its origins in the quite tangible sense of wonder and mystery that was felt by those who originally inhabited this land, in this case, those who lived along the reaches of the Danube. Indeed, at one point in his analysis of Hölderlin's hymn, Heidegger quotes at some length from the Roman historian, Tacitus, who wrote about the customs of the early Germans in his Germania. Tacitus described one such religious festival centred on 'Hertha', the Germanic name for the terra mater, Mother Earth, who was worshipped in a 'sacred grove with sacrificial offerings'. Tacitus tells how her image was brought to the grove by slaves who, following the ceremony, were swallowed up, during a purification process, in a lake (135). And Heidegger concludes quoting Tacitus: 'from this there stems the hidden terror and the sacred ignorance concerning what it is that is seen by only those who are doomed to death' (1996: 158).

Jacob Grimm (1785-1863), philologist and cultural historian of German language and folklore, likewise set out to describe 'the heathen consecration' of nature in his monumental German Mythology (Deutsche Mythologie), published in four volumes in 1834 (2: 586). Heidegger mentions Grimm but once in his study of 'Der Ister', but the reference comes at a critical moment when the philosopher is attempting to delineate the 'historical dwelling' provided by the river. Here he tells us that 'Hertha, growing verdant, is named together with her children, the sons of the earth', most notably Braga, whom Grimm describes as 'the god of language' (1996: 161). Braga was one of the gods that made up a pantheon in the pagan religion of the Germanic tribes., The term 'pagan' (as Grimm explained in the introduction to his 
work) comes from the Latin 'paganus', which means 'rural', 'rustic' or 'of the country', and as a noun, 'paganus' means 'country dweller, villager.' 'Paganism' (or 'Heidentum', as its German sources frequently call it) celebrated the unity of religion and civic values, spirit and nature, gods and man. These pagan gods, as Grimm makes clear, were not simply colourful deities, the stuff of fiction or legend, but expressions for the pagan mind of the power and mystery of its most elemental reality: nature, where 'a god could take on a physical presence in the real world' (Ewing: 47). The forests, mountains and lakes received, in Grimm's words, 'a living consecration from the presence' of these 'individual gods' (I: 4 and III: liv). The elements of nature were worshipped in their own right (II; 647). Indeed, 'all nature was thought of by the heathen mind as living', in a world in which the spirit dwelt amongst 'all-penetrating, all-absorbing primitive substances': 'Water, the limpid flowing, welling up or running dry; Fire, the illuminating, kindled or quenched; Air unseen by the eye, but sensible to ear and touch; Earth, the nourishing, out of which everything grows, and into which all that has grown dissolves' (I: 69 and II: 583). Even 'stones and rocks' represented an indestructible divine presence (II: 465).

This sense of wonder survived in the pagan mind even as the old gods disappeared. Worship of the elements represented, as Grimm observes, 'the last, the all but indestructible remnants of heathenism; when gods collapse, these naked substances come to the front again' (I: 69). It is this interconnectedness of the elements that also provides the foundations for Heidegger's fourfold, in which 'four voices ring out: heaven, earth, man and god' (Heidegger 2000a: 194). It is a manifold presence, as Heidegger tells us in 'Building Dwelling Thinking', which nevertheless possesses a unity, 'a primal oneness': 'the four - earth and sky, divinities and mortals - belong together in one'. And he continues: 'this simple oneness of the four we call the fourfold. Mortals are in the fourfold by dwelling'. They take both the heavens and the earth as their ground' (Heidegger 1971: 149 and 150).

Pagan worship took place within an enclosed space or sacred precinct. Such a place 'served for the community as a model of the original centre, set up at creation when order emerged from chaos' (Davidson: 25). It was a space that, as Grimm describes it, embraced for the pagan mind all elements of the physical world: 'everything shews that the notions of time, age, world, globe, earth, light, air, and water ran very much into one another' (II: 582). Familiar to the Greeks as temenos, this area demarcated a terrain that was set apart from the quotidian world by 'boundary markers' 
(Ewing: 68). To enter the temenos was to make a 'transition from the notion of time to that of space', in which the absolute acquired immediate presence (Grimm II: 790). As Jennifer Gosetti-Ferencei has noted, this was a transition that Heidegger also made in his work, where he came to contemplate time and space 'not in any visualizable coordination but as 'locale' and 'whiling' ', which is 'not given in measurable coordinates' but is 'a form of temporality that evades positive configuration' (193). Indeed, Heidegger's concern with the concept of space as 'topos' grew as his work developed. Heidegger employed various tropes for this notion of space, such as 'the site' ('Ort'), 'the Open' ('Offene'), 'the region' ('Gegend'), all of which are diverse in their provenance but nevertheless converge upon the idea of 'topos'. As he explained in Parmenides, 'topos is the Greek for 'place', although not as mere position in a manifold of points, everywhere homogeneous. The essence of the place consists in holding gathered, as the present 'where', the circumference of what is in its nexus, what pertains to it and is 'of' it, of the place' (1992: 117). The topos is not simply an area of demarcation, a state that de-fines; it is also an area that empowers, which permits the gathering and extension of Being. Topos when seen as 'site' acquires a quality that suggests a transformative presence:

Originally the word 'site' ('Ort') suggested a place in which everything came together, is concentrated. This site gathers unto itself, supremely and in the extreme. Its gathering power penetrates and pervades everything. The site, the gathering power, gathers in and preserves all it has gathered, not like an encapsulating shell but rather by penetrating with its light all it has gathered, and only thus releasing it into its own nature (1982: 159-60)

When we enter the site, we enter a realm of unconcealedness ('Unverborgenheit'). In this realm, 'man is allowed to look up, out of it, through it, towards the divinities. The upward glance passes aloft toward the sky, and yet it remains below on the earth. The upward glance spans the between of sky and earth' (1971: 220). The glance is seeking openness, ('Lichtung'), a space that is, as Heidegger observes in 'The End of Philosophy and the Task of Thinking', experienced in contrast to dense forest: 
The substantive 'opening' goes back to the verb 'to open'. To open something means: to make something light, free and open, e.g. to make the forest free of trees at one place. The opening thus originating is the clearing [which] is not only free for brightness and darkness, but also for resonance and echo, for sounding and diminishing of sound (1972: 65).

It is an appropriate environment for the pagan mind. Tacitus mentions more than once that the pagans worshipped out of doors: 'their holy places are woods and groves, and they apply the names of deities to that hidden presence which is seen only by the eye of reverence', he recounts in Germania (109). Jacob Grimm likewise tells us that 'temple also meant wood. What we imagine to ourselves as a built and walled house, resolves itself, the further back we go, into a holy place untouched by human hand, embowered and shut in by self-grown trees. There dwells the deity, veiling his form in rustling foliage of the boughs' (I: 69 and 70). And Grimm adds, 'in the sweep and under the shade of primeval forests, the soul of man found itself filled with the nearness of Sovran deities' (I: 70).

For the pagan mind, the hallowed forest was a place that accommodated the gods; where even the individual trees seemed to link heaven and earth. In his comments on one pagan source, Davidson tells of 'a mighty tree marking the centre [of the forest] and forming a link between man and the gods' (24). In a later essay, 'Language' ('Die Sprache', 1950), Heidegger celebrated such trees in almost rhapsodic detail:

The tree roots itself soundly in the earth. It flourishes thus into a blooming that opens itself to heaven's blessing. The tree's towering has been called. It spans both the ecstasy of lowering and the soberness of the nourishing sap. The earth's abated growth and the sky's open bounty belong together. The poem names the tree of graces. Its sound blossoming harbors the fruit that falls to us unearned - holy, saving, loving towards mortals. In the golden-blossoming tree there prevail earth and sky, divinities and mortals. Their unitary fourfold is the world (1971: 201).

It is precisely such pantheistic sentiments that inform Heidegger's reading of Adalbert Stifter's 'Ice Tale', ('Eisgeschichte', 1846), a text in which he believed the wonder of the forest had been given full expression. In his story, Stifter depicts a world whose 
mystery resides in an inner silence that is formed from the simple elements of earth, stone, wind and rain, out of whose presence the supernatural shines forth. The story begins in mid-winter and describes the narrator and his companion, during a storm, going into a forest where "the glimmer of the snow stands out against the darkness of the tree trunks standing in rows' (Stifter in Heidegger 2002b: 286). The two men enter in 'wonderment or fear', for not only is the frozen forest dangerous, it is it is also an uncanny place, of oscillating light and darkness, of silence and strange noise. It is a world that seems possessed by a paranormal agency:

A piercing sound of breaking, very much like a cry, came forth. There then followed a brief fluttering, whistling or a scraping sound, and then a dull, rumbling falling noise, of a mighty tree falling to the ground. A crashing sound went through the forest like a roar and through the thicket of damp branches. There was also a ringing and a shimmering, as if an infinity of glass was being pushed together and shaken (Stifter in Heidegger 2002b: 197).

In the preface to his story, Stifter celebrated the minor modulations of the quiet power of nature, which he saw in "the blowing of the wind, the trickling of water, the growing of the corn, the billowing of the waves, the greening of the earth', for they are but 'effects of much higher laws'. Heidegger reads the words of Stifter's story in the same fashion, accepting that:

The powers and laws that the writer points to are themselves only just a sign. For they show in this sign that which is entirely invisible, and yet which precedes it as the alldetermining presence, to which man, in the depths of his being, must conform if he wishes to dwell on this earth. Stifter calls it the great thing ['das Grosse'] (2002b: 197).

It is in the forest, as Heidegger explains, that we experience the presence of the fourfold, the vis primitiva activa that 'gathers everything to itself, which in this manner releases every being to its own self' (2002b: 45). When we enter the forest we must do so in a spirit of devotion, attuned to its mystery, its power to transform. Bringing oneself to this world requires the childlike faith of our ancestors. It is here that the figure of Johann Peter Hebel (1760-1826) is of crucial importance to the development of Heidegger's philosophy of the fourfold. Hebel, a native of Swabia, was a story writer, poet and evangelical theologian, the author of Allemanian Poems (Allemannische Gedichte) first published in 1803, and the folk tales Treasure Chest of 
the Family Friend from the Rhine (Schatzkästlein des rheinischen Hausfreundes, 1803-1819). The author, who took regional themes as his subject matter and wrote in the language of his home province, has been dismissed by some as a dialect writer, as a producer of 'rustic poetry', whose idiom was simplistic and 'naïve' (Bambach: 196). Yet it was precisely the naiveté of Hebel's language, Heidegger argues, that allowed him to make contact with the elemental. Nature appears in Hebel's work in an unmediated way, not through stylised imagery (as we might find in the poetry of the Romantics), but as the simple expression of natura naturans. He wrote alive to the deeper intangibility of the world, those 'quiet spirits' that surrounded him, ghostlike forms that often remain without voice in his writing but nevertheless can be felt as part of the 'greater whole of his work' (2002b: 176).

Hebel believed in a bond between the spiritual and the physical, the human and the vegetative. As he once wrote, 'we are plants, which [...] must rise out of the ground from our roots, in order to bloom in the ether and be able to bear fruit' (Hebel in Heidegger 2002b: 150). As in Heidegger's fourfold, so too in Hebel's world: the elements partake of the same reality, and form an animistic union as in his poem, 'Summer's Evening' ('Der Sommerabend'), which Heidegger discusses in his essay 'Language and Homeland' ('Sprache und Heimat', 1960). The poem tells of a woman who, as she combs her hair, catches the sun's rays. In his interpretation, Heidegger asks us to consider the exact relationship between the woman and the sun:

Who can deny that here $[\ldots]$ the sun is being compared to the motherly farmer's wife? Or is it the other way round: the nature ['das Wesende'] of the wife and mother appears in the great heavenly image of the sun? Is then one being merely compared with the other at all? It is likely that the poem is not making a comparison but is using an image of identity ['Gleichnis']. For 'gleich' means 'gelich' - collected into a sameness, in the same shape (2002b: 179).

Hebel, in short, is not simply using a literary trope. What the sun and the farmer's wife have in common is not a similarity but a shared identity. We are being asked to believe that, in one essential sense, the sun and the woman are the same.

In the introduction to his House Friend (Hausfreund), Hebel had written: 'the House Friend hopes to encourage its readers to consider what reveals itself in the events and conditions of nature, which are at work throughout our inhabited world' 
(2002b: 144). Heidegger also lived, when he chose to be on the land, bounded by the elements, by the 'gravity of the mountains and the hardness of their primeval rock, the slow and deliberate growth of the fir-trees, and the brilliant [and] simple splendour of the meadows in bloom' (1981: 28). Those who dwell here are aware of 'the selfsufficiency of the power to let earth and heaven, divinities and mortals enter in simple oneness into things' (1971: 60).

It is a world in which Heidegger also dwelt as in an environment of truth, because, as he tells us in 'The Nature of Language', 'thinking abides in that country, walking the ways of that country' (1971: 74). Indeed, Heidegger's project of enquiry belonged to the 'path' or 'way'. As a trope, it appears throughout his writing, foregrounding the philosopher's belief in the movement of thought, its energy. The path represents the activity of the mind, which seeks to explore, remaining sensitive to its changing environment, and learning, in the spirit of eundo assequi ('to obtain something along the way'), as it moves forward, although the path may not necessarily have any clear destination (1971: 66). The paths that we walk, it is true, may sometimes be mere 'Holzwege', forest ways that are simply rough tracks used by woodsmen. Not intended for common traffic, they may seem to be directionless, as they meander from one part of the forest to another, coming to 'an abrupt stop where the wood is untrodden' (2002c: v). Such paths can be walked, but only by those who understand their deeper logic, which sustains itself on darkness and confusion.

In his Teutonic Mythology, Jacob Grimm described the pagan belief in the interchangability of human and natural forms, known as 'banning' ('bannen') (II: 951). So too on Heidegger's path: he walks in a terrain where worlds flow into one another and where mystery dwells in everything. In his short prose work, 'The Pathway' (1969), he tells us of one particular walk that he took around his native Messkirch. As he sets out, he relates (in a discourse of extended animism) how 'the old linden trees in the Schloss garden gazed after it [the path] from behind the wall'. The path responds: 'along its edges the pathway greets a tall oak under which stands a roughly hewn bench' (1973: 33). If we have ears to hear, we will learn much from a nature that is now given a voice, which enunciates its presence clearly:

The oak itself spoke: only in such growth is grounded what lasts and fructifies; growing means this: to open oneself up to the expanse of heaven and at the same time 
to sink roots into the darkness of earth. Whatever is genuine thrives only if man is both in right measure: ready for the appeal of highest heaven and preserved in the protection of sustain earth (1973: 35).

Those who choose to take this path must open themselves to what is around them. For as we are further told, 'the pathway's message awakens a sense which loves the Free [open space] and, at a propitious place, leaps over sadness and into a final gladsomeness' (1973: 37). It is a gladsomeness (but also a serenity) that comes from contact with the informing spirit that animates nature, and which points beyond the material world. It does not, however, point to philosophy (as we understand it); on the contrary, to reach our goal we may have to undo ideas, or, at least, return to the ground from which ideas come before enunciation. We must learn from what is simply standing before us:

The Simple conserves the puzzle of what abides and what is great. Spontaneously, it enters men and yet needs a lengthy growth. With the unpretentiousness ['Unscheinbaren'\} of the ever Same, it hides its blessing. The expanse of all growing things that dwell along the pathway grants the world. In the unspoken of their language- as Eckhardt, the old master of latter and life, says - is God, only God (1973: $35)$.

In 1964, Heidegger undertook a visit to Greece and the Greek islands, accompanied by his wife, Elfride, and his friend, Eckart Peterich, a journalist and writer, who had lived and worked in the Aegean for most of his life. In conversations during the course of their visit, the philosopher and the writer frequently returned, Heidegger reported in his travelogue, to a theme that engrossed each equally: the connection that existed for the Greeks 'between the countryside, myth and godhead' (2000a: 260). What was remarkable about this connection was not that it existed, but that the Greeks possessed no words to describe it, nor words for notions such as 'countryside', 'feeling for nature' ('Naturgefühl') or even 'experience ('Erlebnis'). The spiritualisation of the natural world was a self-evident reality for the Greeks: the countryside was not the countryside', but 'the godhead itself'. It is an identification that has been destroyed, Heidegger argues, by the 'Roman-Christian concept of nature', which has inserted a critical breach between the two (2000b: 260).

Through his conception of the fourfold, Heidegger sought to reconstitute that self-evident reality. It is certainly open to us to read that conception in humanistic 
terms, as revealing a concern for the environment and a commitment to an ecological cause. This reading, however, loses sight of the specific reality on which the fourfold was, for Heidegger, grounded, which, as Mark Wrathall has argued, dwelt in the 'holy precincts' of the commonplace, in that which surrounds us, objects both natural and made by man and woman, whose simple physical presence may reveal the divine (207). It is the goal of thought to reveal this presence, and it is here that for Heidegger the mission of philosophy lay, not in the speculations of metaphysics, but in the renewal of vision. For, as Heidegger argued in one of his final publications, 'man can neither pray nor sacrifice to this god [metaphysics]. Before the causa sui, man can neither fall to his knees in awe nor can he play music and dance before this god' (1969: 72).

\section{References}

Bambach C (2003) Heidegger's Roots: Nietzsche, National Socialism and the Greeks. Ithaca: Cornell University Press.

Foltz B V (1995) Heidegger, Environmental Ethics and the Metaphysics of Nature. New York: Humanity Books, 1995.

Grimm J (1966) Teutonic Mythology, translated from the fourth edition by James Steven Stallybrass, four volumes. New York: Dover Publications.

Heidegger M (1969) The Onto-Theo-Logical Constitution of Metaphysics. In Heidegger M (1969) Identity and Difference. Chicago: University of Chicago press, 1969, pp. 42-74.

Heidegger M (1971) Poetry, Language, Thought. New York: Harper \& Row.

Heidegger M (1973) The Pathway. In Listening: Journal of Religion and Culture 8 (1973): 33-39.

Heidegger M (1977) The Question Concerning Technology. In Lovitt W (ed) The Question Concerning Technology and Other Essays. New York: Harper \& Row, Heidegger M (1980) Hölderlin's 'Germania' and 'Der Rhein'. Frankfurt am Main: Klostermann. 
Heidegger M (1982) On the Way to Language. San Francisco: Harper-Collins.

Heidegger M (1996) Hölderlin's Hymn 'The Ister'. Bloomington and Indianapolis: Indiana University Press.

Heidegger M (1999) Contributions to Philosophy (From Enowning). Bloomington: Indiana University Press.

Heidegger M (2000a) Elucidations of Hölderlin's Poetry. New York: Humanity Books.

Heidegger M (2000b) Zu Hölderlin. Griechenlandreisen. Frankfurt am Main: Vittorio Klostermann.

Heidegger M (2002a) Phenomenological Interpretations in Connection with Aristotle: An Indication of the Hermeneutical Situation. In: van Buren J (ed) Supplements: From the Earliest Essays to 'Being and Time' and Beyond. Albany: State University of New York Press, pp. 111-145.

Heidegger M (2002b) Aus der Erfahrung des Denkens. Frankfurt am Main: Vittorio Klostermann.

Heidegger M (2002c) Off the Beaten Track. Cambridge: Cambridge University Press. Heidegger M (2012) Bremen and Freiburg Lectures. Bloomington: Indiana University Press.

Kleinberg E (2005) Generation Existential: Heidegger's Philosophy in France, 19271961. Ithaca: Cornell University Press.

Rojcewicz R (2006) The Gods and Technology: A Reading of Heidegger. Albany: State University of New York Press.

Tacitus (1970) The Agricola and The Germania. Harmondsworth: Penguin Books.

Wrathall M (2011) Between the Earth and The Sky: Heidegger on Life after the Death of God. In Wrathall M (2011) Heidegger and Unconcealment: Truth, Language, and History. Cambridge: Cambridge University Press, pp. 195-211. 
Zimmernan M E (1996) Martin Heidegger: Antinaturalistic Critic of Technological Modernity. In: Macauley D (ed) Minding Nature: The Philosophers of Ecology. New York: The Guilford Press, 1996, pp. 59-81. 